\title{
Reinventing the political party in Spain: the case of 15M and the Spanish mobilisations
}

Abstract: The current political context in Spain is intriguing for those who study participation and political parties. The emergence of citizen activism, expressed mainly through the $15 \mathrm{M}$ Movement, and the political crisis of the two major political parties has led to a new and complex situation where new political parties flourish out of citizen initiatives. This paper analyses the nature and characteristics of these new political parties, and considers the impact that the proliferation of these parties is having on current democracies. The work is based on content analysis and field interviews involving almost a hundred activists and party members from three different Spanish cities.

Key Words: Political parties, representation, post-representative politics, 15M, Activism

Since the economic crisis unleashed by the Global Financial Crisis hit Spain in 2008, the number of new political parties has exploded. Between 2009 and 2010, The Spanish Ministry of Internal Affairs reports that 295 new political parties were registered. This doubled in the period of mobilisation that occurred between 2011 and 2012, with 492 new parties created. ${ }^{1}$ Some of the parties, such as Podemos (We Can!) and Partido $X$ (Party X), emerged from the 'street' or the assemblies and occupations that characterised the mobilisation. Others, such as the Partido Pirata (Pirate Party), emerged from the movement against Internet censorship. There are amalgamations formed from those sharing similar perspectives such as the ecological party EQUO. There are amalgamations of existing parties, disaffiliated activists and independent actors such as Guanyem Barcelona (Let's Win!) led by Ada Colau, associated with the direct action grouping Platforma Afectados per Hipotecas (PAH). ${ }^{2}$ There are revamped regionally based parties, such as the Candidatura d'Unitat Popular-CUP-(Popular

\footnotetext{
${ }^{1}$ https://servicio.mir.es/nfrontal/webpartido_politico.html It should be noted that a significant percentage of these new parties only operate at the local level though as we make clear in the text, the proliferation of new parties at the national level is still remarkable.

${ }^{2}$ Guanyem is the catalan term for let's win. Ganemos is the Spanish version of this concept.
} 
Unity Candidacy), and there are parties that have already built a strong membership base since the 2011 mobilisations, such as Escaños en Blanco (White Seats). Others are still in a state of flux and evolution such as Construyendo la Izquierda (Bulding the Left), the regionally based Procés Constituent a Catalunya (Constituent Process of Catalonia) and the many local "Ganemos" parties, which inspired by the example of Guanayem Barcelona, are starting to reproduce this model in numerous cities and towns across Spain (Ganemos Madrid, Ganemos Málaga, etc.).

At one level, these developments should be welcomed by those who see a healthy and vibrant range of parties as essential to representative democracy. On the other hand, there are puzzles to be explained as well. Firstly, how to explain the explosion of political parties given the picture of decline in parties painted by political scientists over the past decade (Dalton, 2004; Lawson, 2010; Whiteley, 2011; Van Biezen, Mair and Poguntke, 2012). Even where this image is challenged, i.e. by those who stress the adaptability of parties in the form of cartels, or looser coalitions of the disaffected, or because they offer a superior basis for mobilising than available alternatives, the rapid proliferation of parties is nonetheless unexpected - and largely unanticipated - in the broader literature on parties and party systems (Budge, 1996; Dalton, Farrell and McAllister, 2011; Van Biezen, 2014). What explains the sudden preference for the party form over other types of non-affiliated or disaffiliated forms of organisation, which we are told is now the mode of preference for the politically active citizen (Diani and McAdam, 2003; Castells, 2012)? Was not the era of digital media and ICT-based political activism supposed to make political parties redundant? Secondly, as is well documented (Castells, 2012), the Spanish mobilisations were characterised by occupations, street protests and assemblies of a highly participatory type that engaged, 
according to estimates, between 6.5 and 8 million citizens (FnfEurope, 2013). Given this extraordinary engagement, which is seemingly based on a rejection of political parties and the system of representation as a whole (Hughes, 2011), how is it that the mobilisations appear to have given increased impetus to the proliferation of a new generation of political parties? Thirdly, what does this proliferation of parties tell us, more broadly, about the future of 'party-based democracy' in Spain and elsewhere? Does this proliferation support party-based democracy of the type typical in the west European political system, or are we seeing an important change in the relationship between citizens, parties and governance?

Based on our research, the key drivers for the proliferation of new parties are 1) the context of crisis in Spain, one that engulfed the political class as a whole, including the two major political parties in Spain, the PSOE and the PP ${ }^{3}$ 2) the dramatically reduced transaction costs of creating parties as a result of advances in digital media technologies; 3) the perceived limitation of 'street politics', direct action and other kinds of direct and indirect lobbying in leveraging change in the institutions and practices of Spanish democracy. This has meant that even 'horizontal' activists attached to assemblies and occupations have begun to view the electoral system as a possible tool for political advance, one that does not necessarily compromise the ideals of 'street'based activism. The result is that the new parties depart significantly from traditional mass membership political parties, which in turn impacts both the nature and meaning

\footnotetext{
${ }^{3}$ According to CIS survey -Centro de Investigaciones Sociológicas- the vote intention in October 2014 for PP is $27,5 \%$, while for PSOE it is $23,9 \%$ - a total of $51.4 \%$ of the vote. This results show different support for the two main Spanish parties in relation to the results of the last elections. In the March 2008 election, PSOE and PP attained a total of $83.81 \%$ of the vote $(43.87 \%$ for PSOE and $39.94 \%$ for PP). In November 2011, the two parties attained $73.39 \%$ of the total vote (44.63 for PP and 28.76 for PSOE). See: http://www.cis.es/cis/opencms/ES/11 barometros/Indicadores_PI/politica.html http://ep00.epimg.net/descargables/2014/11/05/f65f19988a09564864ddb9414be2f785.pdf(Accessed 16 December 2014).
} 
of party-based democracy, particularly in crisis-afflicted countries such as Spain and the connotations of the term 'participation' which has increasingly come to stand for nonparty or disaffiliated forms of activism.

\section{Methodology}

The methodology is based on a case study of the political effects and trajectory of the $15 \mathrm{M}$ movement. We aim, from a qualitative approach, to explore the nature of the new political parties. The methodology combines two techniques: first, in-depth interviews, and second, content analysis of journalistic materials, websites, Facebook pages and Twitter accounts. The interviews were held with several new and traditional political parties: Podemos, Partido X, CUP, Guanyem Barcelona, Escaños en Blanco, Partido Pirata, EQUO, Izquierda Unida (United Left) and PSOE (socialist party). ${ }^{4}$ The study was completed in three phases: the first in Barcelona $\left(17^{\text {th }}\right.$ March through $21^{\text {st }}$ March 2013), the second in the cities of Valencia and Castellón $\left(14^{\text {th }}\right.$ June through $21^{\text {st }}$ June 2013) and the third in Barcelona, Valencia and Castellón (28 $8^{\text {st }}$ July through $2^{\text {nd }}$ August 2014). This field research involved activist groups and party members from small, medium and large cities. In total, 40 interviews were conducted for a total duration of

\footnotetext{
${ }^{4}$ The list of groups interviewed include:

Podemos: Barcelona (2), Valencia (5), Sagunto (3), Castellón (3), London (1)

Partido X: Barcelona (3), Castellón (1), Valencia (3)

CUP: Barcelona: (3)

Escaños en Blanco: Barcelona (1), Valencia (1), Castellón (4)

Partido Pirata: Castellón (3) and Valencia (2)

EQUO: Castellón (2)

Izquierda Unida -IU-: Valencia (1)

PSOE: Barcelona (1), Valencia (1).

Total of people interviewed: 40
} 
51 hours of interview material. We held one-to-one interviews, small group interviews and larger group workshops to permit a free flow of opinion. ${ }^{5}$

Additionally, we analysed multiple sources and inputs from various origins, which are grouped into three main types:

1) Thirteen new political parties' websites.

2) Thirty-two journalistic and media materials about new political parties.

3) Sixteen key Facebook pages and a hundred messages about activism and political parties delivered through social media channels such as Twitter (see Table 1).

The study focuses on those parties that have been consolidated or created since 2011 . Specially significant for this study are new parties, such as Podemos, Partido X, Guanyem Barcelona and CUP. These political parties can be characterised as citizens' initiatives emerging from social movements, with the ambition to run candidates for the next elections and thus potentially challenge the traditional parties.

The aims of this research are:

(1) To study the nature and form of the new parties.

(2) To explore the characteristics of these new parties and their differences from traditional parties.

(3) To reflect on the meaning of this proliferation of new parties for party-based democracies.

\footnotetext{
${ }^{5}$ Our fieldwork notes can be found on the Author 1 academia page (http://usyd.academia.edu/Author 1). Only the first names of the activists have been used to preserve anonymity.
} 
Table 1

\begin{tabular}{|c|c|c|}
\hline Party name & Podemos & Guanyem Barcelona \\
\hline $\begin{array}{l}\text { Websites } \\
(+ \text { http://) }\end{array}$ & podemos.info & guanyembarcelona.cat/es/ \\
\hline $\begin{array}{l}\text { Facebooks } \\
(+ \text { http://www.) }\end{array}$ & $\begin{array}{l}\text { facebook.com/pages/Podemos/ } \\
269212336568846 \\
\text { (908.423 fans) }\end{array}$ & $\begin{array}{l}\text { facebook.com/guanyem.barcelona } \\
\text { (18.189 fans) }\end{array}$ \\
\hline Twitter accounts: & $\begin{array}{l}\text { @ahorapodemos } \\
\text { (462K followers) }\end{array}$ & $\begin{array}{l}@ \text { guanyem } \\
\text { (26K followers) }\end{array}$ \\
\hline $\begin{array}{l}\text { Participation } \\
\text { channels } \\
(+ \text { http://) }\end{array}$ & $\begin{array}{l}\text { Reddit: plaza.podemos.info } \\
\text { Loomio and Agoravoting: } \\
\text { podemos.info/participa }\end{array}$ & guanyembarcelona.cat/es/participa/ \\
\hline Party name & Partido X & CUP \\
\hline $\begin{array}{l}\text { Websites } \\
(+ \text { http://) }\end{array}$ & partidox.org & cup.cat \\
\hline $\begin{array}{l}\text { Facebooks } \\
(+ \text { http://www.) }\end{array}$ & $\begin{array}{l}\text { facebook.com/PartidoXPartidodelFuturo } \\
\text { (85.701 fans) }\end{array}$ & $\begin{array}{l}\text { facebook.com/CUPBarcelona } \\
\text { (6.587 fans) }\end{array}$ \\
\hline Twitter accounts: & $\begin{array}{l}\text { @ Partido_X } \\
(45,6 \mathrm{~K} \text { followers })\end{array}$ & $\begin{array}{l}\text { @ cupnacional } \\
(57,6 \mathrm{~K} \text { followers })\end{array}$ \\
\hline $\begin{array}{l}\text { Participation } \\
\text { channels } \\
(+ \text { http://) }\end{array}$ & Nexo: http://nexo.partidox.org/ & (Local assemblies) \\
\hline $\begin{array}{l}\text { Other new parties } \\
\text { website consulted }\end{array}$ & \multicolumn{2}{|c|}{$\begin{array}{l}\text { Escaños en Balnco: http://esconsenblanc.org } \\
\text { EQUO: http://partidoequo.es } \\
\text { Partido Pirata: http://partidopirata.es } \\
\text { Partido de Internet: http://partidodeinternet.es } \\
\text { Construyendo la izquierda: } \\
\text { http://contruyendolaizquierda.blogspot.com.es/p/manifiesto.html }\end{array}$} \\
\hline $\begin{array}{l}\text { Other new parties } \\
\text { facebook } \\
\text { consulted }\end{array}$ & \multicolumn{2}{|c|}{$\begin{array}{l}\text { Escaños en Blanco: facebook.com/pages/Escaños-en-Blanco } \\
\text { Partido Pirata: www.facebook.com/partido.pirata } \\
\text { Partido de Internet: www.facebook.com/pages/Partido-de-Internet- } \\
\text { PDI/168786883166140 } \\
\text { EQUO: www.facebook.com/EQUOpartido } \\
\text { Ganemos Madrid: www.facebook.com/ganemosmad } \\
\text { Ganemos Málaga: www.facebook.com/GanemosMalaga }\end{array}$} \\
\hline $\begin{array}{l}\text { Other new parties } \\
\text { Twitter accounts } \\
\text { consulted: }\end{array}$ & \multicolumn{2}{|l|}{$\begin{array}{l}\text { Partido Pirata: @partido_pirata } \\
\text { Escaños en Blanco: @escanosenblanco } \\
\text { Partido de Internet:@ @pdi } \\
\text { Ganemos Madrid:@GanemosMadrid } \\
\text { Ganemos Málaga: @GanemosMalaga }\end{array}$} \\
\hline
\end{tabular}

\section{$15 \mathrm{M}$ and the new political parties: a question of context}

Spain, along with a number of other European countries, has experienced the bitter legacy of the global financial crisis in a wider political crisis encompassing elites and even the royalty. This crisis can hitherto be considered as a key stabilising factor in Spain's transition to democracy. The collapse of banks and savings institutions exposed the political system in direct and harsh ways (Alonso, 2014; Castells, 2012). Many 
regions and cities spent lavishly on prestige projects, funded by generous credit facilities that teetered on the brink of bankruptcy (Charnock, Purcell and Ribera-Fumaz, 2011; Kennedy, 2012). In the glare of a sceptical press and public, many politicians were implicated in financial mismanagement and corruption ${ }^{6}$. Politicians from both major parties, the PP and the PSOE, were exposed and held up to ridicule as selfinterested, power hungry and far removed from the experiences and lives of ordinary people (FnfEurope, 2013).

The perceived decline in legitimacy of the political class resulted in extensive mobilisations, which took the form of non-violent citizen protests and extraparliamentary street politics (Flesher Fominaya, 2014a; Author 2, 2012a; Andronikidou and Kovras, 2012). The Arab Spring in 2008 and the Iceland protests in 2009 served as inspiration for the popular mobilisation in Spain now referred to as $15 \mathrm{M}$, after the 15 th May 2011 call-out (Castells, 2012; Della Porta, 2013). Social media was used by activists to mobilise thousands of citizens, first to organise demonstrations and later to occupy public spaces in all of Spain's major cities and many towns and villages (Bennett and Segerberg, 2012; Postill, 2013; Fuster Morell, 2012; Author 2, 2012b). The occupied spaces quickly took on the role of alternative sites for political mobilisation (Castañeda, 2012). Activists set up assemblies and deliberative forums to organise the occupations and to formulate a strategy in relation to the political crisis (Della Porta, 2013). Blog and Facebook pages were created, Twitter hashtags launched, and a range of other technological means deployed to generate a directly participatory

\footnotetext{
${ }^{6}$ Since 2009, surveys from the CIS, Centro de Investigaciones Sociologicas (Sociological Research Centre), have noted a steady discrediting of the political class. During this period, the quality of political leadership and political parties has become the third greatest concern amongst citizens. Since July 2013, the proliferation of scandals has meant corruption has become the public's second most important concern. Information available at: http://www.cis.es/cis/opencms/ES/11_barometros/indicadores.html (Accessed 12 December 2014).
} 
network (Postill, 2013; Anduiza, Cristancho and Sabucedo, 2013; Toret, 2013). The occupations were claimed by supporters to be "horizontal" (Castells, 2012: 129-130; Hughes, 2011: 410-411; Castañeda, 2012: 313). This is to say that they enacted a style of participatory politics in which every person had a say or a voice, no leaders were elected, and no one was mandated to represent the movement to the media or to the authorities (Micó and Casero-Ripollés, 2013). When a decision needed to be made, it was achieved by the entire assembly of those gathered, operating on the basis of a consensus model of decision making (Taibo, 2013). Should anyone disagree with a proposal, they could block it with the simple gesture of forming an ' $\mathrm{X}$ ' with their arms above their head.

In view of the laborious and time-consuming nature of this style of politics, it is not surprising that within months many of the assemblies and occupations wound down to the point where many were moribund or disappeared altogether. This created a dilemma for politically committed activists: how best to advance the various causes and issues that had generated the mobilisations in the first place?

What becomes clear is that many activists, though not all, concluded that it was only by engaging in the electoral process that momentum could be maintained. With the waning appetite for assemblies and occupations, a more durable basis for keeping pressure on elites was needed, which led to the creation of political parties. We can see this in terms of the types of parties created since 2008 , many of which fall under one or more of the following headings: 
(a) As a tool of protest against the political class

$15 \mathrm{M}$ was directly inspired by the desire to change the mindset or behaviour of political elites (Castells, 2012; Della Porta, 2013). Because the assemblies were only partially successful at attaining this end, more direct means were needed to make the point stick. With this in mind, Podemos' European electoral campaign of 2014 focused on a constant critique of political elites and more specifically of what the party calls the “political caste" (la “casta”). Podemos' political message is based on a binary opposed relation between elites and citizens. As Errejón, campaign director, claimed after 25 May election: "In Spain we saw that on the one hand, we had the political caste, and on the other, the citizens". ${ }^{7}$ Podemos members insist on this idea arguing that "Podemos is more than a left party, it is a protest party against the caste" (Podemos member Castellón 1), "political participation has been so far the property of the elites but this is no longer the case. Citizens have a voice in this movement-party (Podemos member Valencia 1). The anti-elite character is a relevant feature as well of Guanyem Barcelona. This political project emerged early in 2014 with the goal of winning the 2015 Barcelona local elections, giving forces associated with $15 \mathrm{M}$ a power base from which to criticise the national elite and demonstrate a better mode of governance based on ethical political practice. To this end they declared themselves open to alliances with all parties except, according to Colau, "the parties of the political regime directly responsible for the failed model of governance in Barcelona, but the country itself. This excludes PP, PSOE and CiU". ${ }^{8}$

\footnotetext{
${ }^{7}$ In ELPAÍS “Podemos: A party under construction" (May 27, 2014) http://elpais.com/elpais/2014/05/27/inenglish/1401183536 963613.html

${ }^{8}$ Arturo Puente, Joäo França and Enric Català interview Ada Colau in ElDiario.es “Ada Colau: No queremos ir al ayuntamiento para tener algún concejal, queremos ganar" 28 de junio de 2014 http://www.eldiario.es/catalunya/Ada-Colau-Guanyem-Barcelona-queremos-PepitoGrillo_0_275772433.html
} 
Similarly Escaños en Blanco was created with the aim of highlighting the failure of the existing political class. ${ }^{9}$ This would be achieved by "running candidates at elections who promised not to take up their seat in the regional or national Parliament" (EB member 1). This would result in a 'blank seat' acting as a symbolic reminder of the anger and disillusionment of the voting public. Escaños en Blanco does not have a manifesto or a programme aside from this simple idea. As explained via its social media channels, the programme consists of one single driver: "the promise of all party members in leaving empty the seat, giving up any kind of remuneration or privilege derived from the act of being elected". ${ }^{10}$ Escaños en Blanco does not offer solutions to the wider economic and social crisis. It sees itself as a single goal organisation, which is "to make visible citizens' dissatisfaction with the political class and make evident the fact that citizens do not feel well represented by politicians" (EB member 1). This means that the organisation can present itself as non-ideological and 'above the fray'. It also means that its internal organisation is simple and relatively non-hierarchical. Because there is neither policy to be debated nor programme to be formulated, it can "concentrate on strategic and tactical issues" (EB member 2).

\footnotetext{
${ }^{9} \mathrm{http} / / /$ esconsenblanc.org

${ }^{10} \mathrm{https}: / /$ www.facebook.com/pages/Escaños-en-Blanco
} 
(b) As a mechanism for bringing the 'street' directly into politics

An interesting facet of the current situation is the willingness of 'street' activists to use the party as a vehicle for mobilisation and a means of highlighting the limitations of the present political system. Partido $X$ was created by activists identifying with the horizontal wing of $15 \mathrm{M}$. The point of the party is, as one activist put it, to "disrupt the system, put out of office the politicians and recover the power to the people" (PX member 1). Partido $X$ seeks to promote a "true democracy where the citizens have a voice and control over decisions that affect us" (PX member 2). In sum, this would mean a decentralised model of democracy known as democracia y punto - democracy "full stop". ${ }^{11}$ As one Partido $X$ member put it, "now that ICT allows it, it is time to introduce new forms of government that recognise society's ability to improve its own institutions and laws autonomously" (PX member 2).

Podemos, has by contrast, developed a political structure that seeks to promote assembly-style decision making. Participation in the party has been channelled through local groups that are known as "circles" (circulos) referencing the Bolivarian circles associated with the early years of Chavez's regime in Venezuela. Over the first half of 2014 more than 400 working groups sprung up across city neighbourhoods, villages and towns. The circles seeks to foster political debates on the nature of the party and its platform as well as formulating responses to local political issues. ICT has been used to promote elections for its candidates and for the elaboration of the political program. In words of a member of Podemos Valencia "we employ an assembly method for the

\footnotetext{
${ }^{11} \mathrm{http}: / /$ partidox.org/programa/
} 
decision making processes in our circles and we use digital tools to facilitate certain decisions".

By contrast, CUP has restyled itself as a party of the street, having long been a conventional autonomist party of the left. After 15M CUP adopted many of the slogans associated with the Zapatista movement in Mexico, stressing the importance of ordinary people in the generation of proposals: "Nosaltres no us representem, vosaltres ens representeu a nosaltres" ("It is the people who represent themselves to the party, not the Party that represents the people"). David Fernández, a member of the party notes, "the traditional left parties have claimed, till today, to act as intermediaries, mediating conflicts through the Parliament. We are not intermediaries. Who knows more about the problem of evictions than the Plataforma Afectados por la Hipoteca - PAH - (Stop Evictions Platform)? Or who knows more about gender violence than the feminist movement? Our duty is to put ourselves in service of social movements and give them the space to talk directly in Parliament Committees". ${ }^{12}$ CUP encourages participation by both members and non-members of the party, holding public assemblies and committing itself to an open style of decision making. It now defines itself "as an assembly based political party, where there are no representatives but delegates and where the decisions are largely discussed in those cities and towns where it exists" (CUP Party member 1).

Other parties have a similar approach. For example, Guanyem Barcelona's first steps as a political project has consisted in organizing neighbourhoods assemblies in order "to discover what Barcelona's citizens really think and what their real political concerns

\footnotetext{
${ }^{12}$ Interview in Atlantica. $20^{\text {th }}$ of August 2013 http://www.atlanticaxxii.com/1753/david-fernandezcabeza-de-lista-de-la-cup-de-la-crisis-salimos-mas-libres-o-mas-esclavos
} 
are" (Guanyem member 1). This platform intends "to start a democratic process from below with the citizenship participation. The goal is "to consolidate an open and plural process that brings back the city to citizens and that finishes with corporate colonization of local politics" (Guanyem member 2).

EQUO is similarly committed to horizontal forms of decision making. A green left party founded in the first half of 2011, EQUO encourages all those sharing its concerns to participate in the 'EQUO-community', a virtual network in which major issues are discussed in open workgroups, such as 'the environment', 'economy', 'equality' and 'democracy'. This party claims to "work for the creation of a broad socio-political movement that fosters sustainable solutions $[\ldots]$ and new channels and mechanisms for citizen participation". 13

(c) As a means for advancing the project of direct, participatory or 'post-party' forms of direct democracy

Whilst all the new political parties seek to highlight deficiencies in the existing democratic process, a number of them are seeking something more radical: the remodelling of the Spanish democratic system in the direction of greater participation, perhaps even towards a variant of direct democracy based on the use of ICT. Here, we can mention initiatives such as Partido $X$ and the Partido Pirata, the local branch of the now well-established Pirate movement that has already enjoyed electoral success in Germany and Scandinavia. The initial inspiration for the Pirates was the clamping down on pirate and torrent Internet software sites by worried authorities. However, it has now

\footnotetext{
${ }^{13} \mathrm{http} / /$ partidoequo.es/quienes-somos
} 
developed a more substantial 'libertarian' platform in defence of individual liberties and the right to participate directly in government. Their aim, shared with other 'technopolitical' parties such as Partido $X$, is to dissolve representative party-based democracy altogether and replace it with 'liquid democracy'. This would be a form of decision making associated with the 'liquid feedback' initiative, which employs ICT technology to permit individuals to have a voice in policy development or to delegate their input to an 'expert' of their own choosing, which could in turn be revoked at any time. ${ }^{14}$ The model seeks, in the words of the Pirata, to "guarantee a greater potential participation of ordinary citizens that enables the right to vote and participate in relevant political decisions" (Pirate Party Member 1). Similarly, Partido $X$ members claim the "citizens' right to exercise their right to vote on continuous and permanent bases". ${ }^{15}$

\section{Digital media and the new parties}

Political and economic crises have thus been major factors behind the explosion in the number of new political parties. Many of the new parties have been created by those combating austerity and committed to the 'horizontal' practices associated with the early stages of $15 \mathrm{M}$, in particular the occupations and assemblies. The failure of the organised left, of PSOE and the trade unions is thus a key factor explaining the emergence of many of the new parties. However, what becomes equally clear is that the development of ICT has permitted many activists to cross the once-gaping divide between horizontalism and party-based, or vertical, forms of organisation to the extent where it is has to be questioned whether this axis is able to clearly capture what is at stake in the different wings and tendencies of 15M (Author 1, 2005). What seems more

\footnotetext{
${ }^{14}$ The Liquid Democracy Organisation. Available at: https://iqd.net/en

${ }^{15} \mathrm{http}: / /$ partidox.org/programa/
} 
the case is that ICT is changing the ecology of parties, in turn reducing the perceived risk of emerging oligarchical tendencies which formed the basis of the horizontal critique of the party form. What are the characteristics of the changed ecology?

Pop-up parties: Many of the new political parties in Spain are quick fix, temporary or рор-up initiatives designed quite explicitly to take advantage of a moment of political crisis to advance a particular set of issues, such as disillusionment with politicians or Internet censorship. This is not to say that the activists behind such initiatives do not want to create longer term and more lasting organisations. It is that the ability to organise very quickly via the Internet, particularly Facebook, means that it is possible to create an immediate presence, making the detailed fleshing out of a programme or a manifesto a matter for a later date. ${ }^{16}$ Within hours a political party can be set up, a logo created and certain key demands or key issues expressed via a Facebook page. It is in the nature of such evanescent political organisations that they can disappear just as quickly as they emerge; hence, the analogy not only with the pop-up shop but also with a mushroom field. At moments of high political crisis such as we find in Spain after 2011, political experimentation becomes the new norm. Some initiatives will succeed and others will fail. It is already clear for example that the extraordinary success of Podemos has meant that some parties with a similar outlook - in particular Partido $X$ -

\footnotetext{
${ }^{16}$ The fast growth of the new parties through Facebook can be observed with the case of Partido $X$ and Podemos. After only a few months of existence of their Facebook page in 2013

(https://www.facebook.com/PartidoXPartidodelFuturo), a study from the concluded that Partido X facebook page reached the strongest level of engagement from users and has become the second page in the creation of new content. In 2014 the launch of Podemos was even more impressive reaching an extraordinary level of followers. In December 2014, Podemos reached a total number of 911.712 followers. Ahead from PP 79.513 and PSOE 75.435. Partido $X$ total number of followers at that same moment was 85.801. Interactive Advertising Bureau study available at: http://www.iabspain.net/wpcontent/uploads/downloads/2013/11/Informe_comparativo_Partidos_Politicos_Espa\%C3\%B1oles_Faceb ook.pdf
} 
have already seen their fortunes wane as activists realise it is in their interests to consolidate their efforts electorally.

Cheshire cat initiatives: The primary purpose of many parties is to achieve a goal, the realisation of which would make the party itself redundant or obsolete. Even those committed to a more expansive programme saw their initiatives as of limited duration. Partido $X$ defines itself as a "citizens pressure group that seeks to force a change in the democratic system" (PX member 3). To accomplish this goal the party seeks a “citizens' covenant that agrees to demand a political system based on transparency, the permanent right to vote and wiki government" (PX member 4). Once these changes are introduced - by the party or by any other political party - this initiative will disappear. ${ }^{17}$ The Partido Pirata's goal, the creation of 'liquid democracy', would lead to the obsolescence of political parties, including their own. Escaños en Blanco announces that its "disappearance will come when a reform of the electoral law takes into account the votes of protest". ${ }^{18}$ This implies that the system would recognise formally Escaños en Blanco as a vote option with no need for any party to represent this option. The idea of these parties is to create an intervention in the political field that leads to longer term structural, cultural or systemic changes, which would in turn mean their work is complete. It is not clear yet whether Podemos, the most successful of the recent initiatives, will follow the same path. Given that they have won seats in the European Parliament and appear to be developing greater organisational capacity it may be that they develop in a 'left populist' direction in which case, some of the evanescent properties we are documenting will begin to solidify in a manner more familiar to the history of left parties.

\footnotetext{
${ }^{17} \mathrm{http}: / /$ partidox.org/preguntas-frecuentes/

${ }^{18} \mathrm{https}: / / \mathrm{www}$. facebook.com/esconsenblanc
} 
Limited ambit claims: The characteristic of the new parties is that they have a clear view about certain aspects of the current situation that they wish to see addressed. However, few if any of the new parties have anything like a comprehensive worldview or ideology of the type associated with traditional mass parties. Offering a comprehensive alternative was observed as much less important than highlighting a particular and specific policy outcome or systemic alteration they would like to achieve. They seek to highlight citizens' disaffection and to "pressure politicians to force them to pursue their political activity in a more ethical and respectful way". ${ }^{19}$ (Escaños en Blanco), to foster "universal and free access to internet" ${ }^{, 20}$ (Partido Pirata) ${ }^{21}$, "to bring directly the citizens' decisions and votes into parliament" $^{\text {22 }}$ (Partido X). Again, Podemos may well develop along different lines, with a more traditional set of demands expressed in the form of a manifesto albeit one generated 'from the bottom up' - or with the appearance of strong bottom up input.

Anti (elite) politics - The new parties are 'anti-political' in the sense of rejecting the hierarchical structure and discourse of traditional political parties constructed on a neat division of labour between the leadership, cadres and mass membership. If there is one characteristic that unites many current initiatives, it is their rejection of the figure of the 'politician' along with the idea of the party as a vehicle for individuals to assume leadership positions. This has led to some interesting dilemmas given the historic focus of party politics on identifying charismatic leaders, not least for media purposes. Podemos faces the challenge of combining and find a balance between the charismatic

\footnotetext{
${ }^{19} \mathrm{https}: / / \mathrm{www}$. facebook.com/esconsenblanc/info

${ }^{20} \mathrm{https}$ //partidopirata.es/conocenos/programa

${ }^{21} \mathrm{http}: / / \mathrm{www} \cdot \mathrm{pp}$-international.net/about

$22 \mathrm{http}: / /$ partidodeinternet.es/
} 
character of their leader and media star, Pablo Iglesias, with the circles assembly model. Many of those we interviewed considered it necessary for electoral purposes to have such as figure whilst acknowledging that it may pose problems now and in the future. However they remained optimistic that the 'bottom' or street would be able to control the top. As one noted, "Podemos is much more than Pablo Iglesias. The circles ensure that this will remain the case" (Podemos member 1). Others argued that "it is a necessary 'evil' to have such a media figure" (Podemos member 2) adding that "Pablo Iglesias is crucial for the current phase; but once the activists at the base are empowered he will cease to lead the movement" (Podemos member 3).

Partido $X$ has grappled with offering alternatives to personality-centred politics, baulking at the idea of running named candidates in favour of virtual candidates or anonymous candidates. Partido $X$ has decided to choose their representatives through a “system of citizens' open lists (...). Possible candidates for running elections will be proposed by the members of the party and by citizens. The final decisions of candidates will be taken by all those supporters in a complete open process". ${ }^{23}$ Partido $X$ is keen to avoid being led by a charismatic leader because it sees itself as a "party of, and for, the citizens of this country". ${ }^{24}$ Escaños en Blanco will run with named candidates, but only on the basis that such candidates will renounce their seat if elected. Other parties, such as CUP, elect their delegates in open assemblies where the activist base, and not just party members, can be involved. The assemblies determine the salary of candidates and the duration of the political term of their members (with a maximum of one reelection). ${ }^{25}$ The discourse of all the parties was noticeably antipathetic towards the

\footnotetext{
${ }^{23} \mathrm{http}: / /$ partidox.org/preguntas-frecuentes/

${ }^{24} \mathrm{http}$ ://www.theguardian.com/world/2013/oct/20/partido-x-spain-politics-financial-crisis

${ }^{25} \mathrm{http}: / /$ cup.cat/noticies/participacio
} 
identification of any individual as a potential or actual leader. These are all self-styled 'parties without politicians' in the Latin American mould - or anti-party parties.

A means to an end - The new political parties are political tools as opposed to the privileged vehicle of a distinct ideology or conception of how we should live. Ideology is not, in general, a relevant component of the new parties. Despite defining themselves as a 'left' party, activists identifying with Podemos saw themselves as above or beyond ideology as such. One argued that "we do not believe in the traditional distinction of right and left (...). We are simply those at the bottom of the system struggling against the elite" (Podemos member 3). For Flesher Fominaya "it is precisely an antiideological stance, a refusal to self-define in terms of political ideologies (...) that has marked an important element of the effective Podemos strategy". She concludes that “Podemos has presented itself as a party of 'decent ordinary people', who understand the needs of ordinary citizens and are open to taking their lead from them through the participatory process. They want to go beyond acronyms" (Flesher Fominaya, 2014b, 2).

Interestingly, surveys of voter intentions conducted in October and November 2014 indicates the success of Podemos in uncoupling the critique of the political and economic elites from a leftist classical discourse. As the ideological composition of voter intentions proves, their anti-elitist stance and message concerning the need to address the moral shortcomings of Spain's elites is gaining electoral ground ${ }^{26}$.

\footnotetext{
${ }^{26}$ CIS surveys show that in October 2014 Podemos became the third most popular party in Spain with $22,5 \%$ of voters expressing a preference for the party. A Metroscopia survey in November and December 2014 estimated the popularity of Podemos at 25\%, ahead from PP $20 \%$ and very close to PSOE $27,7 \%$. CIS shows that the composition of Podemos votes is diverse since this is coming not only from abstentionist (15,5\%) spoiled votes (36,4,5\%), and from the left $(45,6 \%$ from United Left and $27,4-$ $28,8 \%$ from PSOE) but also from more conservative ideological positions: among 27,4\% and 28,8 \% from the liberal party UPyD, among 6,6 and 9,8\% from the regionalist conservative CiU, and more surprisingly $6 \%$ from PP voters. This survey indicates, thus, that $6 \%$ of former 2011 national election PP
} 
Elsewhere Partido $X$ stresses that "our principles do not correspond to any ideology, but with a pragmatic methodology"27, while Escaños en Blanco defines itself as a "nonideological initiative". ${ }^{28}$ As one activist behind the Partido $X$ initiative put it, "we have tried to change politics through protests on the streets, it is time now to try something different and see what happens" (PX member 5). New parties such as Partido $X$ have been created out of the failure of the occupations and assemblies to force change on to the political agenda of elites. That failure to force change in turn forced a reappraisal of tactics, leading to the creation of parties as a 'next best' mode of organising, but still a party that might have the required leverage to force reconsideration of the electoral law, the investigation of corruption and the possibility of advancing to a more direct democracy.

The pragmatic and instrumental approach of today's party activists contrasts markedly with the type of activism associated with the heyday of traditional mass political parties (Dalton, 2002; Holliday, Farrell and Webb, 2002). It in turn problematises the differentiation between mainstream, or electoral, politics and other types of participation that could be read as a supplement to the main business of politics. In the latter understanding, other types of political participation are viewed as important on their own terms. However, they do not ordinarily displace the centrality of political parties within politics. Indeed, to bring us back to the problem animating this paper, it is

voters are now intending to vote Podemos in next 2015 national elections. This percentage is higher in the Metroscopia survey, which estimates that $8 \%$ of former PP voters intend to vote for Podemos, and in the Celeste-Tel polls, which found a percentage of $24.7 \%$ for the same type of voter. Information available at: CIS-October:http://ep00.epimg.net/descargables/2014/11/05/f65f19988a09564864ddb9414be2f785.pdf (Accessed: 12 December 2014)

Metroscopia - Surveys of November and December: http://elpais.com/tag/metroscopia/a/, http://www.metroscopia.org/ and http://blogs.elpais.com/metroscopia/2014/12/barometro-electoral-diciembre-2014.html Celeste-Tel - Survey of November 2014: http://www.eldiario.es/politica/ENCUESTA-cuarta-Podemosprocede-PP_0 326868090.html (Accessed 13 December 2014)

${ }^{27} \mathrm{http}$ ://partidox.org/preguntas-frecuentes/

${ }^{28} \mathrm{http}$ ://escanos.org/ 
precisely the decline of political parties that makes political scientists so nervous about future prospects for democratic governance and representation (Whiteley, 2011). However, in Spain what we find is a pragmatic instrumentalisation of the party form itself. For activists, the party is "one kind of political tool" yet far from the only one (PX members 6 and 7). Indeed, as the comments above indicate, there remains a residual suspicion about the party form itself, which means that the attachment to the party is contingent upon and mediated by other factors of a strategic and tactical type. ICT has lowered the costs of creating parties, but it appears to have lowered the level of emotional attachment to them as well.

\section{The impact of the new parties on 'Party-based democracy'}

On the basis of what has been discussed thus far, it is clear that those who fear the decline and the potential disappearance of political parties within representative democratic systems can be confident that the party is not 'over'. Indeed, in the face of the proliferation of parties in crisis-afflicted societies such as Spain, one might invert the sentiment and argue that the party has only just begun. On the other hand, what also becomes clear is that the coordinates of party politics are changing rapidly. This in turn will have an impact on 'party-based democracy'. The question is how?

Firstly, as far as Spain is concerned it should be noted that the main objective of the new parties is less to contest power directly than to draw our attention to deficiencies or shortcomings in the practice of democracy itself. One of the key slogans of $15 \mathrm{M}$ was "Democracia Real, iya!" (Real Democracy Now!) What that slogan flagged was the belief that the existing democratic process was, in certain respects, flawed (Author 2, 
2014). $15 \mathrm{M}$ thus revalorised democracy in a manner that underscores findings suggesting that citizens in Western Europe have not given up on democracy, even if they demonstrate alienation from existing representative processes (Wessels, 2011). On the contrary, the point seems to be the need to enrich and deepen the practice of democracy so that instead of equating to the periodic election of politicians, it engages the citizen on a day-to-day basis. Hence, a plethora of new political parties are seeking to extend democracy using Web.2 and peer-to-peer (P2P) technologies. Many parties, such as Podemos, Escaños en Blanco, Partido X, EQUO and Partido Pirata, seek to reform the institutions of democracy and in particular the electoral system, so that they function better. Here, we find an analogy with developments across Europe and elsewhere, for example, the Movimento 5 Stelle (Five Star Movement) in Italy and the newly formed WikiLeaks party in Australia. They are protest parties; but this should not be taken to mean that they are against democracy, which is often the tenor of worried media commentary and political analysis, both of which can tend to conflate mass mobilisations with the 'populist temptation' (von Beyme, 2011; Author 1, 2013). Rather, they seek to draw attention to the deficiencies of democracy and to inspire debate as to how best to address them. In this sense, they might be seen as part of the broader effort of citizen initiatives to improve deliberation, provide greater opportunities for participation, and to close the distance between politics and citizens, and state and civil society. Another way of putting it, is that they seek a more 'connective' mode and style of politics (Bennett and Segerberg, 2012). Elsewhere this might proceed via campaigns for deliberative assemblies, participatory budgeting and so forth. In Spain it proceeds via a direct challenge to the hegemony of the main political parties, to the political and economic elites and the system of representation itself. 
Secondly, the new parties mark a more general shift from durable, lasting forms of political organisation toward evanescent, impermanent and immediate styles of political interaction. The difference between direct or DIY politics and the type of politics that we associate with political parties is becoming more difficult to discern (Diani and McAdam, 2003; Day, 2004; Mertes and Bello, 2004; Castells, 2012; Della Porta, 2013). This reflects the changing ecology of political parties touched on above. In previous decades it took a long time to organise a political party. It required energy and enthusiasm to launch an organisation that would require considerable funding and hours of labour to be viable. This contrasted with varieties of 'individualised collective action', DIY politics, protests and demonstrations, which were often event-based or episodic (Micheletti, 2003). Now that organising has become "ridiculously easy", the party itself is in the process of changing dramatically (Shirkey, 2009). This is not to say that all political parties will change or that they will have to change to survive, though much of the evidence suggests that parties themselves feel the urgent need to harness new technologies to keep themselves relevant. What it means is that the political field will become more complicated for voters to navigate as they are presented with an increasingly complex menu of options from which to choose, ranging from traditional political parties to all types of special interest or protest parties of very recent vintage. The new political parties are part of a broader ecology of an evanescent, liquid, mercurial type. Political parties will come and go from election to election, making our connection to them and to what they represent less secure than the types of affiliation and affinity associated with the traditional party, which often developed deep roots amongst its supporters and in communities. 
In view of the above, the new political parties might, thirdly, be better conceptualised as part of 'Counter democracy' (Rosanvallon, 2008) or 'Monitory democracy' (Keane, $2009,2013)$ than as part of the traditional apparatus of the state and governance. As already discussed, the initial motivation, as well as rationale, for many new political parties is as a way of disrupting the mainstream democratic process, of drawing attention to its limitations and deficiencies. Members of these parties reluctant to view themselves as potential members of government, even as members of a coalition or alliance. On the other hand, events in Spain suggest a scenario of a similar kind to that witnessed in Italy in 2013 when Beppe Grillo's Movimento 5 Stelle -M5S- (Five Star Movement) emerged as the most popular party at the polls. Such is the degree of disaffection amongst the Spanish electorate that it is becoming ever more conceivable that parties born out of protest or the real or virtual 'street' will make significant headway in electoral terms (Garzia, 2013: 1101-1103). The fate of M5S is revealing in this respect. The self-image of the party or movement is that of the outsider, of 'democracy against the state', to paraphrase Abensour (2011). When confronted with its own success in the Italian election of 2013, it was almost as if M5S was paralysed and unable to address the transition from a protest movement to a party of governance. Nevertheless, it is possible to contemplate new parties playing a key role in forcing significant changes to the nature and form of democratic governance, as in Iceland, where a significant public mobilisation resulted in a constituent process to refound the political process, the recomposition of the central bank and the bringing to justice of corrupt politicians (Castells, 2012). 'Counter democracy' need not therefore be theorised merely in terms of a force pressing against the institutions of governance. It may become a force that is transformative of governance itself. 
It is of course rather early to judge the impact that the rise of Podemos might have on the political process in Spain. Certainly its success in winning seats in the European elections was a shock to the traditional parties. Many of the demands of $15 \mathrm{M}$ and the new parties, such as more and better citizen participation, changes in the mortgage law, elimination of parties' and politicians' privileges, etc., have yet to have an impact, at the time of writing, on the discourse or programmes of the two largest traditional parties (PP and PSOE). However a number of studies have shown that $15 \mathrm{M}$ and Podemos are making a considerable impression in the public sphere and the Spanish media, which report daily on the inadequacies of the main parties, the corruption of elites and the need for far-reaching change (Romanos, 2013; Flesher Fominaya, 2014; Micó and Casero, 2012; Author 2, 2012). Where there has been a more tangible impact is in terms of the model of membership of political parties themselves. The new parties are by and large plural organisation with open or near-open membership policies. Many of them do not ask for a fee, and the process of registration to be involved in debates, primaries, candidate selection is usually a formality, if it exists at all. This in turn is impacting the perception of what a political party could and should look like particularly amongst left parties such as IU and PSOE who now want to democratize their political structures, introducing elements such as primaries elections of candidates and transparency measures. So whilst the impact of the discourse of the traditional parties might be currently uncertain, the impact on their organisational form is becoming more noticeable. Parties are having to reach out to connect, to engage and involve those who are now confronted with a battery of alternatives for their loyalty and engagement. In short, the once exclusive model of the 'private party' looks increasingly under strain as the 'street parties' attract members with their inclusive mode of recruiting and organising new members. 


\section{Conclusions}

If the Spanish case is in any way typical, we do not think that political parties are endangered, at least for the present. Even in crisis-afflicted contexts, the appetite to create and build new political parties is obvious. The idea, therefore, that we can associate the shift from classical representative democracy to 'post representative' or 'monitory' styles of democracy with the decline of the political party is unlikely to be borne out in practice. However, the shift in political style from the slow, predictable, mediated forms of politics that we associate with representative democracy to flash politics, evanescent politics, a politics that resonates rather than represents, has made an impact in the nature and form of the political parties emerging in this evolving political galaxy. Nor do we feel that this shift is merely a response to the type of contingent crisis experienced by countries such as Spain that were confronted with the fallout of the global financial crisis. This is as much a story about digital media and the new opportunities it presents to activists as it is about the decline in trust that is also so evident in countries touched by crisis and corruption. What those of us observing politics have to grapple with is the revolutionary potential offered by new digital media to create groups and organisations with a facility that was unthinkable until very recently. Just as the rest of our lives are being transformed by the ease of creating groups, so is politics. For present purposes what this means is that we need to rethink political parties as not just the means for ensuring the 'rotation of elites' in the manner described by Schumpeter (2003: 269-273) but as part of a broader political ecology that is contesting this account of what democracy means and how it functions.

Of course some questions remain unanswered: Given that some of the new protest parties are beginning to find resonance with sections of the electorate, will this mean 
that we can expect a change in the style and substance of democratic politics? Will institutional changes follow altering in some more fundamental way the coordinates of representative democracy? Is it conceivable that democracy itself will be redrawn in some new important way diminishing or even collapsing the space between elites, governance and citizens in a manner promised by Podemos? Or will the new parties tread the 'left populist' path, promising greater citizen participation, 'ethical governance', 'bottom up initiatives' whilst delivering party based - or even presidential - rule of a largely familiar kind? Whatever the case, it seems clear that with street activists developing a taste for party political activism the coordinates of Spanish democracy are set to change in ways that are significant not only for Spain, but for representative democratic systems more generally. 


\section{References}

Abensour, Miguel. 2011. Democracy against the State: Marx and the Machiavellian Moment. Cambridge: Polity.

Alonso, Sonia. 2014. "Votas pero no eliges: la democracia y la crisis de la deuda soberana en la eurozona". Recerca. Revista de Pensament i Anàlisi, 15: 21-53. doi: 10.6035/Recerca.2014.15.2

Andronikidou, Aikaterini and Iosif Kovras. 2012. "Cultures of Rioting and Anti-Systemic Politics in Southern Europe", West European Politics, 35 (4): 707-725. doi: 10.1080/01402382.2012.682342

Anduiza, Eva, Camilo Cristancho and José M. Sabucedo. (2013). "Mobilization through online social networks: the political protest of the indignados in Spain", Information, Communication and Society, 17 (6): 750-764. doi: 10.1080/1369118X.2013.808360

Ankersmit, Frank. 2008. "On the Future of Representative Democracy". Available at: $\mathrm{http} / / / \mathrm{www}$.thefutureofrepresentativedemocracy.org/files/pdf/resources/Ankersmit\%20comm ents.pdf (Accessed 6 August 2013).

Bennett, W. Lance and Alexandra Segerberg. 2012. "The logic of connective action", Information, Communication \& Society, 15(5), 739-768. doi: 10.1080/1369118X.2012.670661.

Budge, Ian. 1996. The New Challenge of Direct Democracy. Cambridge; Polity.

Castañeda, Ernesto. 2012. "The Indignados of Spain: A Precedent to Occupy Wall Street", Social Movement Studies, 11 (3-4): 309-19. doi: 10.1080/14742837.2012.708830

Castells, Manuel. 2012. Networks of Outrage and Hope: Social Movements in the Internet Age. Cambridge: Polity Press.

Charnock, Greig, Thomas Purcell and Ramón Ribera-Fumaz. 2011. “indígnate!: the 2011 Popular Protest and the Limits to Democracy in Spain", Capital and Class, 31: 3-11.

Dalton, Russell J. 2004. Democratic Challenges, Democratic Choices: The Erosion of Political Support in Advanced Industrial Democracies. Oxford: Oxford University Press.

Dalton, Russell J. 2002. Citizen Politics: Public Opinion and Political Parties in Advanced Industrial Democracies. London: Chatham House Publishers.

Dalton, Russell J., David M. Farrell and Iain McAllister. 2011. Political Parties and Democratic Linkage: How Parties Organize Democracy. Oxford: Oxford University Press.

Day, Richard 2004. "From Hegemony to Affinity: The Political Logic of the Newest Social Movements", Cultural Studies, 18 (5): 716-48. doi: 10.1080/0950238042000260360

Della Porta, Donatella. 2013. Can Democracy be saved? Participation, Deliberation and Social Movements. Cambridge: Polity.

Diani, Mario and Doug McAdam. 2003. Social Movements and Networks: Relational Approaches to Collective Action. Oxford: Oxfrod University Press.

Duverger, Maurice. 1959. Political Parties: Their Organization and Activity in the Modern State. London: Methuen.

Flesher Fominaya, Cristina. 2014a. Debunking Spontaneity: Spain's 15-M/Indignados as Autonomous Movement, Social Movement Studies: Journal of Social, Cultural and Political Protest. doi: 10.1080/14742837.2014.945075

Flesher Fominaya, Cristina. 2014b. "Spain is Different: Podemos and 15-M". Open Democracy, May 29, https:/www.opendemocracy.net/can-europe-make-it/cristinaflesher-fominaya $/ \% \mathrm{E} 2 \% 80 \% 9 \mathrm{Cspain}$-is-different $\% \mathrm{E} 2 \% 80 \% 9 \mathrm{D}$-podemos-and- $15 \mathrm{~m}$

FnfEurope. 2013. "The Spanish Slump - Political Crisis and the Need for Institutional Reform". Available at:, http://fnf-europe.org/2013/06/17/the-spanish-slump-political-crisis-and-theneed-for-institutional-reform/ (Accessed 27 November 2013).

Fuster Morell, Mayo. 2012. "The Free Culture and 15M Movements in Spain: Composition, Social Networks and Synergies", Social Movement Studies, 11 (3-4): 386-91. doi: $10.1080 / 14742837.2012 .710323$ 
Garzia, Diego. 2013. "The 2013 Italian Parliamentary Election: Changing Things So Everything Stays the Same", West European Politics, 36 (5): 1095-1105. doi: 10.1080/01402382.2013.815483

Hay, Colin. 2007. Why we hate politics. Cambridge: Polity.

Holliday, Ian, David Farrell and Paul Webb. 2002. Political Parties in Advanced Industrial Democracies. Oxford: Oxford University Press.

Hughes, Neil. 2011. "Young People Took to the Streets and all of a Sudden all of the Political Parties Got Old: The 15M Movement in Spain“, Social Movement Studies, 10 (4): 407-13. doi: 10.1080/14742837.2011.614109

Keane, John. 2009. The life and death of democracy. London: Simon and Schuster.

Keane, John. 2013. Democracy and media decadence. Cambridge: Cambridge University Press.

Kennedy, Paul. 2012. "From Unpopular Socialists to the Popular Party: The Spanish General Election of 2011", West European Politics, 35 (3): 673-681. doi: 10.1080/01402382.2012.665746

Lawson, Kay, ed. 2010. Political Parties and Democracy. Santa Barbara: Praeger.

Mair, Peter and Ingrid Van Biezen. 2001. "Party membership in twenty European democracies, 1980-2000", Party Politics, 7 (1): 5-21. doi: 10.1177/1354068801007001001

Mertes, Tom and Walden F. Bello. 2004. A movement of movements: is another world really possible? New York: Verso.

Micheletti, Michele. 2003. Political Virtue and Shopping: Individuals, Consumerism and Collective Action. New York: Palgrave.

Michels, Robert. 1998. Political Parties: A Sociological Study of the Oligarchical Tendencies of Modern Democracy. New York: Transaction.

Micó, Josep Lluis and Andreu Casero-Ripollés. 2013. "Political activism online: organization and media relations in the case of $15 \mathrm{M}$ in Spain", Information, Communication and Society, 17 (7): 858-871. doi:10.1080/1369118X.2013.830634

Postill, John. 2013. "Democracy in an age of viral reality: A media epidemiography of Spain's indignados movement", Ethnography, 23: 1-19. doi: 10.1177/1466138113502513

Romanos, Eduardo. 2013. Collective learning processes within social movements: some insights into the Spanish 15-M/Indignados movement. In Understanding European movements: new social movements, global justice struggles, anti-austerity protest, edited by Cristina Flesher Fominaya and Lawrence Cox, 203-219. New York: Routledge.

Rosavallon, Piere. 2008. Counter-democracy: politics in an age of distrust. New York: Cambridge University Press.

Saward, Michael. 2010. The representative claim. Oxford: Oxford University Press.

Saward, Michael. 2011. "The Wider Canvass: Representation and Democracy in State and Society. The Future of Representative Democracy". In The Future of Representative Democracy, edited by Sonia Alonso, John Keane and Wolfgang Merkel, 341-346. Cambridge: Cambridge University Press.

Schumpeter, Joseph, A. 2003. Capitalism, Socialism and Democracy. London: Routledge.

Shirkey, Clay 2009. Here Comes Everybody: The Power of Organizing Without Organizations. New York: Penguin.

Taibo, Carlos. 2013. "The Spanish indignados: A movement with two souls", European Urban and Regional Studies, 20: 155-158. doi: 10.1177/0969776412459846

Toret, Javier, ed. 2013. Tecnopolítica: la potencia de las multitudes conectadas. El sistema red $15 \mathrm{M}$, un nuevo paradigma de la política distribuida. Barcelona: UOC.

Van Biezen, Ingrid, Peter Mair and Thomas Poguntke. 2012. "Going, going,... gone? The decline of party membership in contemporary Europe", European Journal of Political Research, 51: 24-56.

Van Biezen, Ingrid. 2014. "The End of Party Democracy as we know it? A Tribute to Peter Mair". Irish Political Studies, 29, 2 177-93.

Whiteley, Paul F. 2011. "Is the party over? The decline of party activism and membership across the democratic world", Party Politics, 17 (1): 21-44. doi: 10.1177/1354068810365505 
(Author 1, 2013)

(Author 1, 2005)

(Author 2, 2012a)

(Author 2, 2012b)

(Author 2, 2014) 